\title{
Pengaruh Pemanasan Terhadap Kuat Tekan Mortar Geopolimer Berbahan Dasar Abu Terbang Kelas C Arie Wardhono
}

\author{
Jurusan Teknik Sipil, Fakultas Teknik, Universitas Negeri Surabaya, Kampus Unesa Ketintang. \\ Email : ariewardhono@unesa.ac.id
}

\begin{abstract}
Abstrak
Sebagai material utama penyusun beton, semen merupakan material yang kurang ramah terhadap lingkungan. Penggunaan abu terbang merupakan salah satu alternatif untuk mengatasi hal tersebut. Namun kendala utama penggunaan abu terbang, khususnya abu terbang kelas $F$, adalah dibutuhkannya panas selama proses pembuatan mortar geopolimer. Penelitian ini bertujuan untuk mengetahui pengaruh pemanasan terhadap kuat tekan mortar geopolimer berbahan dasar abu terbang kelas $C$ yang memiliki kandungan Ca dan Fe cukup tinggi dibandingkan kelas F. Bahan aktivator yang digunakan adalah kombinasi sodium silikat dan sodium hidroksida dengan molaritas 8M dan 12M. Proses pembuatan dilakukan pada temperatur $60^{\circ} \mathrm{C}$ dengan variasi lama pemanasan 3 , 6, 18 dan 24 jam. Hasil penelitian menunjukkan bahwa lama pemanasan mampu meningkatan kuat tekan mortar geopolymer. Kuat tekan awal 3 hari telah mencapai $45.95 \mathrm{MPa}$ (80\%) dan $47.91 \mathrm{MPa}$ (90\%) pada lama pemanasan 24 jam. Kuat tekan usia 14 hari bahkan telah mencapai 98\% dan 100\% terhadap kuat tekan akhir pada molaritas 8M dan 14M. Meskipun pemanasan mampu meningkatkan kekuatan tekan mortar geopolimer, kekuatan yang dicapai mortar geopolimer tanpa pemanasan telah melebihi kuat tekan rencana dan mampu mengatasi permasalahan pemanasan yang terjadi pada abu terbang kelas $F$.
\end{abstract}

Kata Kunci: Abu terbang kelas $C$, geopolymer, kuat tekan, lama pemanasan, mortar

\begin{abstract}
As the primary material of concrete, Portland Cement (PC) has been known as un-environmentally friendly material during production process. Fly ash is one alternative to overcome this issue. However, the main problem of fly ash, particularly class $F$ fly ash, is the heat curing requirement to achieved its structural integrity. The aim of this research is to know the effect of heat curing treatment to the strength development of class $C$ fly ash geopolymer mortar with a higher Ca and Fe content compared to class F fly ash. A combination of sodium silicate and sodium hydroxide was used as activator. The molarity variation is $8 M$ and $12 M$. The specimens were produced under ambient temperature and heat curing at $60^{\circ} \mathrm{C}$ with the curing duration of 3, 6, 18, and 24 hours. The results showed that the duration of heat curing increased the strength development of geopolymer mortar. The early strength (3 days) has achieved $45.95 \mathrm{MPa}$ (80\%) and $47.91 \mathrm{MPa}(90 \%)$ in 24 hours heat curing treatment. The $14^{\text {th }}$ days strength has reached $98 \%$ and $100 \%$ strength of the final strength at 28 days at $8 M$ and $14 M$ molarities. Despite the heat curing treatment can improve the strength of geopolymer mortar, the strength achieved by the un-heated curing geopolymer mortar has exceeded the design strength. It can overcome the heat curing problem on class F fly ash.
\end{abstract}

Keywords: Class C fly ash, geopolymer, compressive strength, heat curing duration, mortar

\section{PENDAHULUAN}

Sebagai salah satu material utama penyusun beton, semen merupakan bahan bangunan yang paling banyak digunakan oleh masyarakat dewasa ini. Namun penggunaan semen membawa dampak negatif terhadap lingkungan terkait dengan emisi gas karbondioksida $\left(\mathrm{CO}_{2}\right)$ yang dihasilkan selama proses produksi semen. Menurut Meyer (2009), produksi semen diperkirakan berkontribusi sebesar 5-7\% dari emisi $\mathrm{CO}_{2}$ di seluruh dunia, dengan produksi 1 ton semen juga menghasilkan sekitar 0.6 ton hingga 1 ton gas $\mathrm{CO}_{2}$, bergantung pada pembangkit listrik (Peng et al., 2013; Li et al., 2011; Huntzinger and Eatmon, 2009). Hal ini mendorong penggunaan bahan limbah seperti abu terbang sebagai bahan pengganti semen dikarenakan sifat abu terbang yang dapat meningkatkan sifat fisik, kimia, dan mekanik dari semen dan beton (Ahmaruzzaman, 2010). 
Penelitian terbaru menunjukkan bahwa adalah mungkin untuk mengembangkan beton geopolimer yang semata-mata didasarkan pada abu terbang yang diaktifkan secara langsung, tanpa kehadiran semen, dengan menggunakan alkali aktivator. Manfaat utama dari beton geopolimer adalah adanya pengurangan emisi $\mathrm{CO}_{2}$ sebesar $26-45 \%$ dengan penggantian semen tanpa efek ekonomi yang merugikan (Soutsos et al., 2016; Singh et al., 2015; Provis, 2014).

Menurut standar ASTM C618 (2004), terdapat tiga jenis abu terbang, yaitu kelas F, kelas $\mathrm{C}$ dan kelas $\mathrm{N}$, yang diklasifikasikan berdasarkan kandungan bahan penyusunnya. Abu terbang kelas $\mathrm{F}$ dan kelas $\mathrm{C}$ umumnya digunakan untuk bahan pengganti semen karena karakteristik pozzolanic-nya. Perbedaan utama antara abu terbang kelas $\mathrm{F}$ dan kelas $\mathrm{C}$ adalah pada kandungan kalsium (Ca), dimana kelas $\mathrm{F}$ memiliki kandungan Ca kurang dari 10\%, sedangkan kadar Ca pada kelas C lebih besar dari $10 \%$.

Sebagai bahan pengganti semen, penggunaan 100\% abu terbang yang dikombinasikan dengan alkali aktivator dapat menggantikan peran semen dalam beton. Penelitian sebelumnya menunjukkan bahwa abu terbang kelas F dapat digunakan 100\% sebagai bahan pengganti semen karena memiliki kandungan silikat ( $\mathrm{Si}$ ) dan aluminat (Al) yang tinggi (Gunasekara et al., 2017; Law et al., 2015). Reaksi antara $\mathrm{Si}, \mathrm{Al}$, dan aktivator membentuk matriks geopolimer melalui reaksi polimerisasi (Davidovits, 1994). Namun, permasalahan utama penggunaan abu terbang kelas $\mathrm{F}$ adalah temperatur tinggi yang dibutuhkan untuk mempercepat reaksi geopolymer dan meningkatkan proses polimerisasi yang terjadi pada matriks geopolymer selama proses pengerasan akibat rendahnya kandungan $\mathrm{Ca}$ (Hardjito et al., 2004 ; Kong and Sanjayan, 2010).

Abu terbang kelas $\mathrm{C}$ yang memiliki kandungan $\mathrm{CaO}$ diatas 10\% (ASTM C618, 2004) diharapkan mampu mengatasi kendala temperatur tinggi pada abu terbang kelas $\mathrm{F}$. Kandungan $\mathrm{CaO}$ yang tinggi pada abu terbang kelas $\mathrm{C}$ membentuk matriks kalsiumaluminat-silikat hidrat (C-A-S-H), matriks yang memiliki perilaku mirip dengan beton normal namun dengan rasio $\mathrm{Ca} / \mathrm{Si}$ yang lebih rendah (Nath dan Sarker, 2015). Hasil penelitian Bakharev et al. (1999) pada beton geopolimer berbahan dasar terak besi (slag) dengan kandungan $\mathrm{CaO}$ lebih dari 10\%, menunjukkan bahwa pemanasan memiliki pengaruh terhadap kuat tekan beton geopolymer dengan kandungan $\mathrm{CaO}$ tinggi. Hasil uji kuat tekan pada benda uji geopolimer dengan lama pemanasan selama 3 jam pada suhu $70^{\circ} \mathrm{C}$ adalah sebesar 14 $\mathrm{MPa}$. Peningkatan lama pemanasan benda uji menjadi 6 jam pada temperatur yang sama menghasilkan sedikit peningkatan kuat tekan menjadi $17 \mathrm{MPa}$. Sedangkan lama pemanasan selama 24 jam menghasilkan kuat tekan yang cukup tinggi sebesar $21 \mathrm{MPa}$ (Bakharev et al., 1999; Wardhono, 2015). Kemiripan kandungan $\mathrm{CaO}$ pada terak besi ini memungkinkan abu terbang kelas $\mathrm{C}$ diproduksi pada temperatur normal.

Penelitian ini menyajikan pengaruh lama pemanasan terhadap perkembangan kekuatan mortar geopolimer berbahan dasar abu terbang kelas C. Pemanasan benda uji dilakukan pada temperatur $60^{\circ} \mathrm{C}$ selama 3 , 6, 18 dan 24 jam dengan variasi molaritas sebesar $8 \mathrm{M}$ dan 12M. Uji kuat tekan dilakukan pada usia benda uji mortar 3, 7, 14 dan 28 hari untuk mengetahui perkembangan kuat tekan benda uji geopolimer.

\section{METODE}

\section{Material}

Material utama penyusun mortar geopolimer adalah abu terbang dari PT. Paiton. Abu terbang yang digunakan adalah abu terbang kelas $\mathrm{C}$ dengan kandungan $\mathrm{Ca}$ dan $\mathrm{Fe}$ yang cukup tinggi sesuai standar ASTM (ASTM C618, 2003). Uji komposisi kimia abu terbang dilakukan dengan uji X-Ray Fluorescence (XRF) menggunakan alat PANalytical type Minipal 4. Komposisi kimia abu terbang kelas $\mathrm{C}$ ditunjukkan pada Tabel 1 berikut.

Tabel 1. Komposisi kimia abu terbang kelas C (\%)

\begin{tabular}{lc}
\hline Komponen & Kandungan \\
\hline $\mathrm{Al}_{2} \mathrm{O}_{3}$ & 3.13 \\
\hline $\mathrm{SiO}_{2}$ & 0.53 \\
\hline $\mathrm{Fe}_{2} \mathrm{O}_{3}$ & 57.24 \\
\hline $\mathrm{CaO}$ & 21.97 \\
\hline $\mathrm{MgO}$ & 0.02 \\
\hline $\mathrm{K}_{2} \mathrm{O}$ & 0.76 \\
\hline $\mathrm{TiO}_{2}$ & 0.92 \\
\hline $\mathrm{Mn}_{2} \mathrm{O}_{3}$ & 0.51 \\
\hline $\mathrm{SO}_{3}$ & 0.01 \\
\hline
\end{tabular}

Abu terbang kelas $\mathrm{C}$ memiliki kandungan $\mathrm{Ca}$ sebesar $21.97 \%(>10 \%)$, total kandungan $\mathrm{SiO}_{2}+\mathrm{Al}_{2} \mathrm{O}_{3}+$ $\mathrm{Fe}_{2} \mathrm{O}_{3}$ sebesar $60.90 \%$ ( $>50 \%$ dan $<70 \%$ ), dan kandungan $\mathrm{SO}_{3}$ sebesar $0.01 \%(<5 \%)$, sesuai dengan ASTM (ASTM C618, 2004).

Kombinasi sodium silikat $\left(\mathrm{Na}_{2} \mathrm{SiO}_{3}\right)$ dengan sodium hidroksida $(\mathrm{NaOH})$ dengan variasi molaritas $8 \mathrm{M}$ dan $12 \mathrm{M}$ digunakan sebagai bahan aktifasi mortar geopolimer.

\section{Komposisi Campuran}

Komposisi campuran mortar geopolimer dikembangkan berdasarkan penelitian sebelumnya (Deb et al., 2014, Wardhono, 2015). Komposisi benda uji mortar ditentukan sesuai dengan standar ASTM (ASTM C109, 2014) dengan rasio pasir terhadap semen $(\mathrm{w} / \mathrm{b})$ sebesar 2,75 . Untuk benda uji geopolimer, digunakan rasio kandungan air terhadap kandungan padatan (w/s). Hal ini disebabkan karena 
total kandungan air pada mortar geopolimer lebih ditentukan oleh jumlah total kandungan air dalam sodium silikat dan $\mathrm{NaOH}$ dan air, sedangkan untuk jumlah total padatan ditentukan dari jumlah padatan terlarut dalam larutan alkali aktivator dan abu terbang (Wardhono, 2015).

Rincian komposisi rencana campuran mortar geopolimer ditampilkan pada Tabel 2 berikut.

Tabel 2. Komposisi mortar geopolimer

\begin{tabular}{lc}
\hline Material & Komposisi \\
\hline Semen & - \\
\hline Abu terbang kelas $\mathrm{C}$ & 1 \\
\hline Pasir & 2.75 \\
\hline Sodium silikat & 0.318 \\
\hline Sodium hidoksida $(\mathrm{NaOH})$ & 0.212 \\
\hline Air & 0.075 \\
\hline
\end{tabular}

Rasio sodium silikat terhadap $\mathrm{NaOH}$ (rasio SS/SH) ditentukan sebesar 1.5 (Deb et al., 2014). Rasio kandungan air terhadap kandungan padatan (w/s) ditentukan sebesar 0.446 dan 0.435 untuk molaritas $8 \mathrm{M}$ dan $12 \mathrm{M}$.

\section{Molaritas dan Perawatan}

Molaritas dan perawatan (curing) mortar geopolimer dapat dilihat pada Tabel 3 berikut.

Tabel 3. Molaritas dan perawatan mortar geopolimer

\begin{tabular}{|c|c|c|}
\hline Benda Uji & Molaritas & Keterangan perawatan \\
\hline GM08-1 & $8 \mathrm{M}$ & Kontrol, suhu ruang \\
\hline GM08-2 & $8 \mathrm{M}$ & Suhu $60^{\circ} \mathrm{C}$, selama 3 jam \\
\hline GM08-3 & $8 \mathrm{M}$ & Suhu $60^{\circ} \mathrm{C}$, selama 6 jam \\
\hline GM08-4 & $8 \mathrm{M}$ & Suhu $60^{\circ} \mathrm{C}$, selama 18 jam \\
\hline GM08-5 & $8 \mathrm{M}$ & Suhu $60^{\circ} \mathrm{C}$, selama 24 jam \\
\hline GM12-1 & $12 \mathrm{M}$ & Kontrol, suhu ruang \\
\hline GM12-2 & $12 \mathrm{M}$ & Suhu $60^{\circ} \mathrm{C}$, selama 3 jam \\
\hline GM12-3 & $12 \mathrm{M}$ & Suhu $60^{\circ} \mathrm{C}$, selama 6 jam \\
\hline GM12-4 & $12 \mathrm{M}$ & Suhu $60^{\circ} \mathrm{C}$, selama 18 jam \\
\hline GM12-5 & $12 \mathrm{M}$ & Suhu $60^{\circ} \mathrm{C}$, selama 24 jam \\
\hline
\end{tabular}

Molaritas mortar geopolimer ditentukan sebesar 8M dan 12M. Perawatan mortar geopolimer dilakukan dengan cara pemanasan. Benda uji mortar yang telah dituang ke dalam cetakan dibungkus dengan pastik tahan panas dan dimasukkan dalam tungku pemanas pada temperatur $60^{\circ} \mathrm{C}$ selama 3, 6, 18 dan 24 jam.

\section{Pengujian}

Pengujian kuat tekan mortar geopolimer dilakukan dengan menggunakan alat uji tekan berdasarkan standar ASTM (ASTM C109, 2004). Uji tekan dilakukan saat benda uji berumur 3, 7, 14, 28 hari.

\section{HASIL DAN PEMBAHASAN \\ Pengaruh pemanasan terhadap kuat tekan mortar geopolimer $8 \mathrm{M}$}

Hasil uji kuat tekan mortar geopolimer dengan $\mathrm{NaOH} 8 \mathrm{M}$ dapat dilihat pada Tabel 4 berikut.

Tabel 4. Kuat tekan mortar $8 \mathrm{M}$ pada temperatur $60^{\circ} \mathrm{C}$ selama $3,6,18$ dan 24 jam

\begin{tabular}{lccccc}
\hline \multirow{2}{*}{ Benda Uji } & \multicolumn{4}{c}{ Kuat tekan (MPa) pada usia (hari) } \\
\cline { 2 - 6 } & & 3 & 7 & 14 & 28 \\
\hline GM08-1 & 0 jam & 24.97 & 31.15 & 42.83 & 44.63 \\
\hline GM08-2 & 3 jam & 29.75 & 33.79 & 39.73 & 48.27 \\
\hline GM08-3 & 6 jam & 34.76 & 43.18 & 48.49 & 52.81 \\
\hline GM08-4 18 jam & 37.74 & 44.19 & 49.70 & 53.34 \\
\hline GM08-5 24 jam & 45.95 & 53.59 & 55.79 & 57.14 \\
\hline
\end{tabular}

Perkembangan kekuatan mortar geopolimer 8M dengan pemanasan pada temperatur $60^{\circ} \mathrm{C}$ selama 3 , 6, 18 dan 24 jam terhadap mortar geopolimer tanpa pemanasan ditampilkan pada Gambar 1, 2, 3 dan 4 berikut.

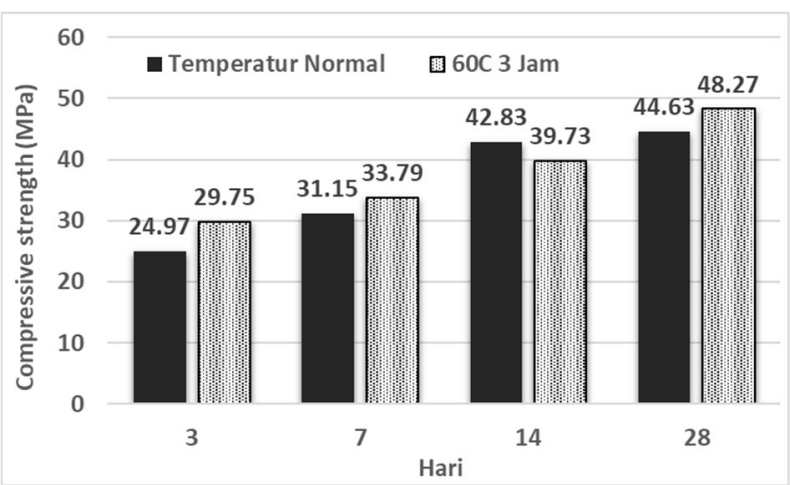

Gambar 1. Kuat tekan mortar geopolimer 8M pada temperatur $60^{\circ} \mathrm{C}$ selama 3 jam

Gambar 1 menunjukkan bahwa pemanasan hanya memberikan sedikit pengaruh terhadap perkembangan kekuatan mortar geopolimer. Pemanasan selama 3 jam pada temperatur $60^{\circ} \mathrm{C}$ hanya meningkatkan kuat tekan sebesar $18 \%$ dari usia 3 hari ke usia 28 hari benda uji.

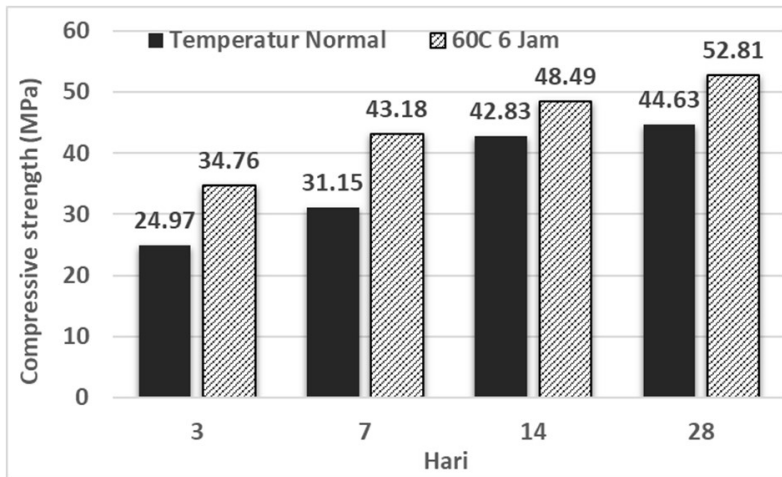

Gambar 2. Kuat tekan mortar geopolimer $8 \mathrm{M}$ pada temperatur $60^{\circ} \mathrm{C}$ selama 6 jam

Gambar 2 menunjukkan adanya sedikit peningkatan kuat tekan mortar geopolimer sebesar 15\% dengan peningkatan rata-rata sebesar $6.02 \mathrm{MPa}$ pada pemanasan selama 6 jam temperatur $60^{\circ} \mathrm{C}$. 


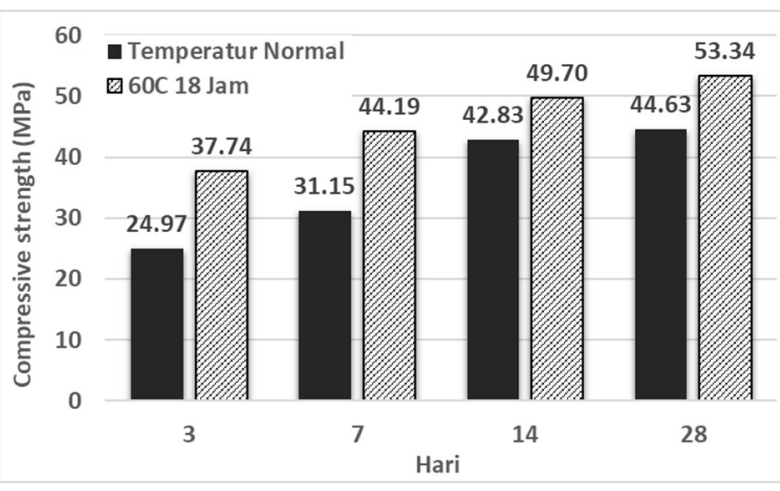

Gambar 3. Kuat tekan mortar geopolimer $8 \mathrm{M}$ pada temperatur $60^{\circ} \mathrm{C}$ selama 18 jam

Penambahan waktu lama pemanasan dari 6 jam menjadi 18 jam mampu meningkatkan kuat tekan mortar geopolimer dari $52.81 \mathrm{MPa}$ menjadi 53.34 MPa pada usia 28 hari (Gambar 3).

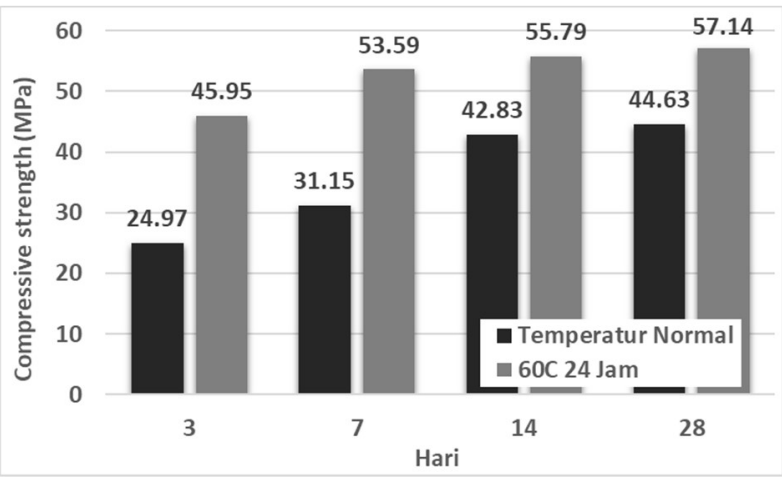

Gambar 4. Kuat tekan mortar geopolimer $8 \mathrm{M}$ pada temperatur $60^{\circ} \mathrm{C}$ selama 24 jam

Gambar 4 menunjukkan bahwa penambahan lama pemanasan menjadi 24 jam pada temperature $60^{\circ} \mathrm{C}$ memberikan nilai kuat tekan tertinggi sebesar 57.14 $\mathrm{MPa}$. Namun, perkembangan kekuatan dari usia 3 hari ke 28 hari cenderung menurun menjadi $8 \%$. Hal ini karena lama pemanasan 24 jam meningkatkan kuat tekan awal (usia 3 hari) mortar geopolimer yang telah mencapai $80.4 \%$ kekuatan pada usia 28 hari.

Gambar 5 menjelaskan bahwa lama pemanasan pada temperatur $60^{\circ} \mathrm{C}$ mempengaruhi perkembangan kuat tekan mortar geopolimer pada molaritas $8 \mathrm{M}$. Peningkatan kekuatan sebesar $84 \%$ terjadi pada kuat tekan awal (3 hari) dari $24.97 \mathrm{MPa}$ (pemanasan 3 jam) menjadi $45.95 \mathrm{MPa}$ (pemanasan 24 jam). Selain itu, peningkatan kekuatan juga terjadi dari pemanasan selama 3 jam ke 24 jam pada usia 28 hari yaitu dari 44.63 $\mathrm{MPa}$ menjadi 57.14 $\mathrm{MPa}$ dengan nilai peningkatan sebesar $28 \%$.

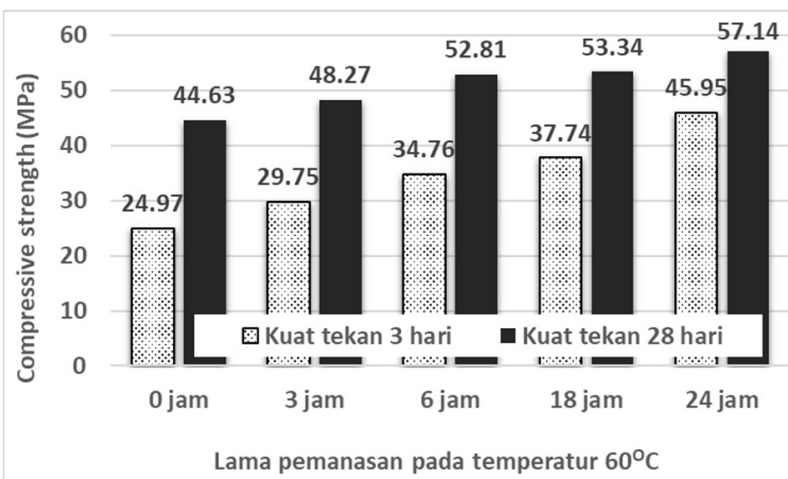

Gambar 5. Kuat tekan mortar geopolimer 8M pada temperatur $60^{\circ} \mathrm{C}$ usia 28 hari

Pengaruh pemanasan terhadap kuat tekan mortar geopolimer 12M

Hasil uji kuat tekan mortar geopolimer dengan $\mathrm{NaOH} 12 \mathrm{M}$ dapat dilihat pada Tabel 5 berikut.

Tabel 5. Kuat tekan mortar $12 \mathrm{M}$ pada temperatur $60^{\circ} \mathrm{C}$ selama $3,6,18$ dan 24 jam

\begin{tabular}{llcccc}
\hline Benda Uji & \multicolumn{4}{c}{ Kuat tekan (MPa) pada usia (hari) } \\
\cline { 2 - 6 } & & 3 & 7 & 14 & 28 \\
\hline GM12-1 & 0 jam & 28.21 & 33.56 & 42.83 & 43.20 \\
\hline GM12-2 & 3 jam & 30.69 & 38.35 & 43.32 & 44.74 \\
\hline GM12-3 & 6 jam & 36.18 & 41.78 & 47.10 & 48.02 \\
\hline GM12-4 18 jam & 46.14 & 52.79 & 51.56 & 52.08 \\
\hline GM12-5 24 jam & 47.91 & 50.50 & 53.92 & 53.20 \\
\hline
\end{tabular}

Perkembangan kekuatan mortar geopolimer 12M dengan pemanasan pada temperatur $60^{\circ} \mathrm{C}$ selama 3 , 6, 18 dan 24 jam terhadap mortar geopolimer tanpa pemanasan ditampilkan pada Gambar 1, 2, 3 dan 4 berikut.

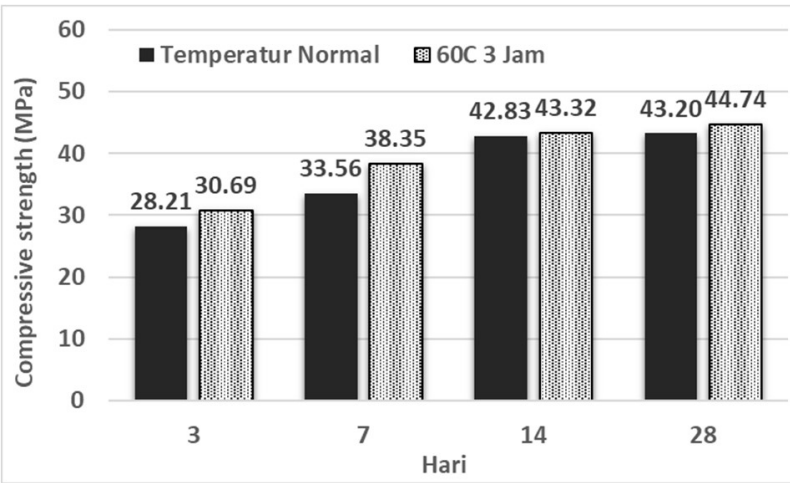

Gambar 6. Kuat tekan mortar geopolimer $12 \mathrm{M}$ pada temperatur $60^{\circ} \mathrm{C}$ selama 3 jam

Gambar 6 menunjukkan bahwa pemanasan tidak terlalu berpengaruh terhadap kekuatan mortar geopolimer. Pemanasan selama 3 jam menunjukkan peningkatan kekuatan sebesar $14 \%$ sampai dengan usia 28 hari dengan kekuatan tertinggi sebesar 44.74 $\mathrm{MPa}$.

Gambar 7 menunjukkan kekuatan geopolimer mortar $12 \mathrm{M}$ akibat pemanasan selama 6 jam. 
Hasil pemanasan menunjukkan peningkatan sebesar $11 \%$ dari $43.20 \mathrm{MPa}$ (tanpa pemanasan) menjadi $48.02 \mathrm{MPa}$. Selain itu, perkembangan kekuatan dari usia 3 hari ke 28 hari menunjukkan perkembangan kekuatan sebesar $10 \%$.

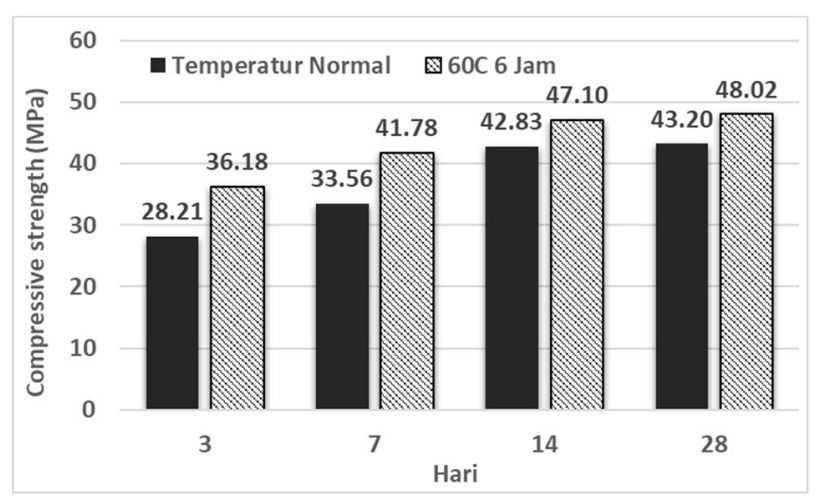

Gambar 7. Kuat tekan mortar geopolimer $12 \mathrm{M}$ pada temperatur $60^{\circ} \mathrm{C}$ selama 6 jam

Pemanasan selama 18 jam pada temperatur $60^{\circ} \mathrm{C}$ pada Gambar 8 cenderung tidak memberikan pengaruh terhadap perkembangan kekuatan mortar geopolimer. Hal ini tampak pada perkembangan kekuatan sebesar $4 \%$ dari usia 3 hari sebesar 46.14 $\mathrm{MPa}$ menjadi $52.08 \mathrm{MPa}$ pada usia 28 hari. Perkembangan kekuatan mortar geopolimer juga cenderung telah berhenti pada usia benda uji 7 hari dengan nilai kuat tekan sebesar $52.79 \mathrm{MPa}$.

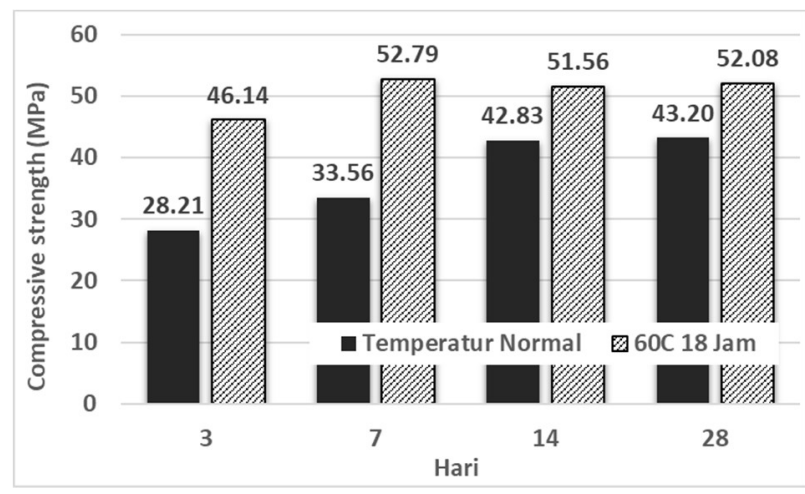

Gambar 8. Kuat tekan mortar geopolimer 12M pada temperatur $60^{\circ} \mathrm{C}$ selama $18 \mathrm{jam}$

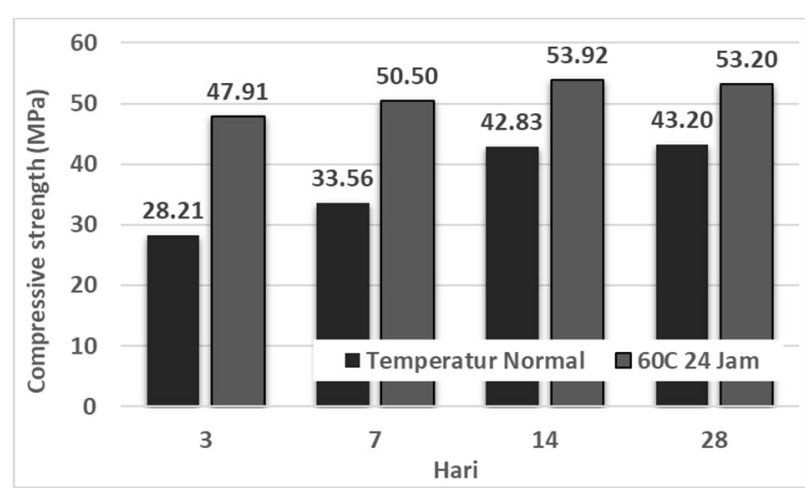

Gambar 9. Kuat tekan mortar geopolimer 12M pada temperatur $60^{\circ} \mathrm{C}$ selama $24 \mathrm{jam}$
Perkembangan kuat tekan mortar geopolimer selama 24 jam pada Gambar 9 mirip dengan pemanasan selama 18 jam. Perkembangan kekuatan cenderung berhenti pada usia 7 hari dengan nilai kuat tekan $50.50 \mathrm{MPa}$. Rata-rata nilai perkembangan kekuatan sebesar 4\% menunjukkan bahwa mortar geopolimer telah mencapai kekuatan akhir di usia awal 7 hari dengan nilai kuat tekan sebesar $90.1 \%$ terhadap nilai kuat tekan 28 hari.

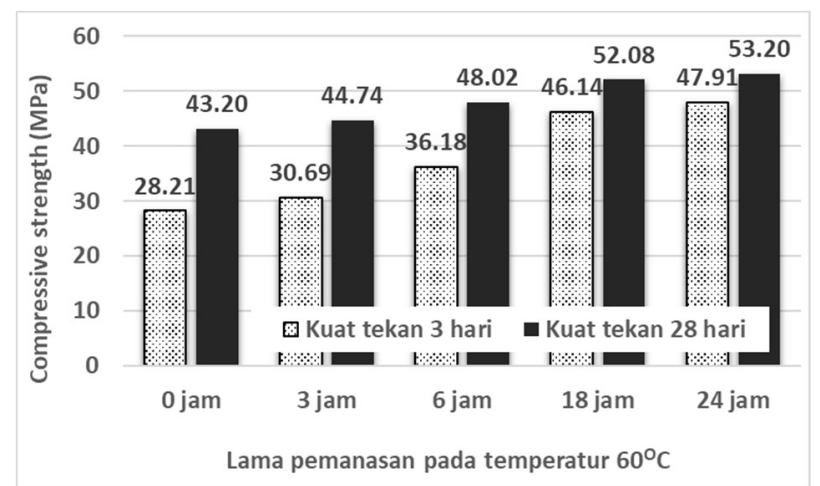

Gambar 10. Kuat tekan mortar geopolimer 12M pada temperatur $60^{\circ} \mathrm{C}$ usia 28 hari

Gambar 10 menunjukkan bahwa lama pemanasan memiliki pengaruh terhadap nilai kuat tekan awal mortar geopolimer berbahan dasar abu terbang dan $\mathrm{NaOH} 12 \mathrm{M}$. Hal ini terutama tampak pada usia 3 hari yang menunjukkan peningkatan kekuatan sebesar $70 \%$ dari $28.21 \mathrm{MPa}$ (tanpa pemanasan) menjadi $53.20 \mathrm{MPa}$ (pemanasan 24 jam). Namun sebaliknya, penambahan lama waktu pemanasan dari 3 jam menjadi 24 jam tidak terlalu berpengaruh terhadap kekuatan mortar geopolimer pada usia 28 hari. Hal ini dapat dilihat pada nilai kuat tekan tanpa pemanasan yang telah mencapai $43.20 \mathrm{MPa}(81.2 \%)$ dari kuat tekan dengan pemanasan 24 jam.

\section{Pengaruh pemanasan kuat tekan geopolimer mortar 8M dan 12M}

Pengaruh lama pemanasan pada temperatur $60^{\circ} \mathrm{C}$ mempengaruhi perkembangan kekuatan mortar geopolimer dengan molaritas $8 \mathrm{M}$. Hal ini tampak pada peningkatan kekuatan pada pemanasan selama 3 jam, 6 jam, 18 jam, dan 24 jam dari usia 3 hari ke 28 hari sebesar $18 \%, 15 \%, 12 \%$ dan $8 \%$.

Meskipun lama pemanasan mampu meningkatkan nilai kuat tekan, lama pemanasan lebih dari 18 jam tidak memberikan pengaruh yang berarti pada perkembangan kekuatan mortar geopolimer. Hal ini ditnujukkan dengan nilai perkembangan kekuatan sebesar $8 \%$ pada lama pemanasan 24 jam.

Perilaku serupa juga terjadi pada mortar geopolimer 12M. Peningkatan kekuatan rata-rata yang terjadi adalah sebesar $14 \%, 10 \%, 4 \%, 4 \%$ pada lama pemanasan 3 jam, 6 jam, 18 jam dan 24 jam. Meskipun lama pemanasan 18 jam dan 24 jam 
memberikan nilai kuat tekan tertinggi, namun perkembangan kekuatan cenderung telah berhenti pada pemanasan selama 18 jam dan 24 jam dengan nilai perkembangan kuat tekan dari usia 3 hari ke 28 hari sebesar $4 \%$.

Tabel 6 menunjukkan pengaruh lama pemanasan terhadap perkembangan kuat tekan geopolimer mortar $8 \mathrm{M}$ dan $12 \mathrm{M}$ pada usia 3, 7 dan 14 hari terhadap kuat tekah akhir pada usia 28 hari.

Tabel 6. Perkembangan kuat tekan mortar geopolimer $8 \mathrm{M}$ dan $12 \mathrm{M}$ terhadap kuat tekan usia 28 hari

\begin{tabular}{lccccc}
\hline Benda Uji & \multicolumn{4}{c}{ Kuat tekan pada usia (hari) } \\
\cline { 2 - 6 } & & 3 & 7 & 14 & 28 \\
\hline GM08-1 & 0 jam & 0.56 & 0.70 & 0.96 & 1 \\
\hline GM08-2 & 3 jam & 0.62 & 0.71 & 0.82 & 1 \\
\hline GM08-3 & 6 jam & 0.66 & 0.82 & 0.92 & 1 \\
\hline GM08-4 & 18 jam & 0.71 & 0.83 & 0.93 & 1 \\
\hline GM08-5 24 jam & 0.80 & 0.94 & 0.98 & 1 \\
\hline GM12-1 & 0 jam & 0.65 & 0.78 & 0.98 & 1 \\
\hline GM12-2 & 3 jam & 0.69 & 0.86 & 0.97 & 1 \\
\hline GM12-3 & 6 jam & 0.75 & 0.87 & 0.98 & 1 \\
\hline GM12-4 18 jam & 0.89 & 1 & 1 & 1 \\
\hline GM12-5 24 jam & 0.90 & 0.95 & 1 & 1 \\
\hline
\end{tabular}

Hasil analisis menunjukkan mortar geopolimer 12M memiliki nilai kuat tekan lebih tinggi dibandingkan dengan geopolimer $8 \mathrm{M}$ pada seluruh usia benda uji. Hal ini tampak pada kuat tekan yang dicapai benda uji pada usia 3 hari untuk $12 \mathrm{M}$ sebesar $65 \%$ dari kuat tekan akhir, lebih besar dibandingkan dengan benda uji $8 \mathrm{M}$ dengan nilai kuat tekan $62 \%$. Demikian juga nilai kuat tekan pada usia 14 hari sebesar $98 \%$ (12M) dan 96\% (8M) dari kuat tekan 28 hari.

Lama pemanasan juga mempengaruhi kuat tekan mortar geopolimer 8M. Hal ini ditunjukkan pada peningkatan kuat tekan awal usia 3 hari geopolimer $8 \mathrm{M}$ dari $56 \%$ menjadi $62 \%$ terhadap nilai kuat tekan akhir. Peningkatan waktu lama pemanasan juga meningkatkan nilai kuat tekan awal terhadap nilai kuat tekan akhir pada usia 28 hari. Hal ini dapat dilihat pada tercapainya kuat tekan sebesar $62 \%$, $66 \%, 71 \%$ dan $80 \%$ seiring dengan bertambahnya lama pemanasan dari 3, 6, 18 dan 24 jam. Demikian pula nilai kuat tekan pada usia 14 hari yang telah mencapai $82 \%-98 \%$ dari kuat tekan 28 hari pada pemanasan 3-24 jam.

Lama pemanasan memberikan efek yang cukup besar pada molaritas yang lebih tinggi. Hal ini ditunjukkan pada nilai kuat tekan yang lebih tinggi dibandingkan pencapaian nilai kuat tekan pada geopolimer 8M. Nilai kuat tekan yang telah dicapai geopolimer $12 \mathrm{M}$ pada lama pemanasan 18 jam adalah sebesar $89 \%$ dan $100 \%$ pada usia 3 dan 14 hari. Nilai ini lebih besar dibandingkan dengan nilai kuat tekan sebesar 71\% (3 hari) dan 93\% (14 hari) pada geopolimer $8 \mathrm{M}$. Nilai kuat tekan geopolimer
12M bahkan telah mencapai $100 \%$ pada usia14 hari pada pemanasan 18 dan $24 \mathrm{jam}$. Hal ini menunjukkan

\section{SIMPULAN}

Simpulan yang didapat adalah sebagai berikut:

1. Pemanasan memiliki pengaruh terhadap perkembangan kekuatan mortar gepolimer berbahan dasar abu terbang kelas $\mathrm{C}$.

2. Lama pemanasan pada temperatur $60^{\circ} \mathrm{C}$ mampu meningkatkan kuat tekan mortar geopolimer $8 \mathrm{M}$ dan $12 \mathrm{M}$.

3. Lama pemanasan 24 jam dapat meningkatkan kuat tekan awal usia 3 hari sebesar $80 \%$ dan $90 \%$ dari nilai kuat tekan akhir molaritas $8 \mathrm{M}$ dan $12 \mathrm{M}$.

4. Kekuatan mortar geopolimer $14 \mathrm{M}$ telah mencapai kekuatan akhir (100\%) pada usia 14 hari pada pemanasan $60^{\circ} \mathrm{C}$ selama $18 \mathrm{jam}$ dan 24 jam. Sedangkan mortar geopolimer $8 \mathrm{M}$ baru mencapai $98 \%$ kekuatan akhir pada usia 14 hari dengan pemanasan 24 jam.

5. Meskipun lama pemanasan pada temperatur $60^{\circ} \mathrm{C}$ mampu meningkatkan kekuatan geopolimer mortar, kekuatan yang dicapai tanpa pemanasan telah melebihi kuat tekan rencana dan mampu mengatasi permasalahan pemanasan yang terjadi pada abu terbang kelas F.

\section{REFERENSI}

Ahmaruzzaman, M., 2010, "A Review on The Utilization of Fly Ash", Jurnal of Progress in Energy and Combustion Science. Vol. 36, No. 3, pp. 327-363.

ASTM Standard, 2004, “ASTM C109: Standard Test Method for Compressive Strength of Hydraulic Cement Mortars".

ASTM Standard, 2004, "ASTM C618: Standard Specification for Coal Fly Ash and Raw or Calcined Natural Pozzolan for Use in Concrete".

Bakharev, T., Sanjayan, J.G., and Cheng, Y.B., 1999, "Effect of Elevated Temperature Curing on Properties of Alkali Activated Slag Concrete", Cement and Concrete Research. Vol. 29, No. 10, pp. 1619-1625.

Davidovits, J., 1994, "Properties of Geopolymer Cements", Proceedings of $1^{\text {st }}$ International Conference on Alkaline Cements and Concretes, Kiev: Scientific Research Institute on Binders and Materials, Kiev,Ukraine, pp. 131-149.

Deb, P.S., Nath, P., and Sarker, P.K., 2014, "The Effects of Ground Granulated Blast-Furnace Slag Blending with Fly Ash and Activator Content on The Workability and Strength 
Properties of Geopolymer Concrete Cured at Ambient Temperature", Materials and Design. Vol. 62, No. October, pp. 32-39.

Gunasekara, C., Setunge, S., and Law, D.W., 2017, "Long-Term Mechanical Properties of Different Fly Ash Geopolymers", ACI Structural Journal. Vol. 114, No. 3, pp. 743752.

Hardjito, D., Wallah, S.E., Sumajouw, D.M.J., and Rangan, B.V., 2004, "On the Development of Fly Ash-Based Geopolymer Concrete", $A C I$ Materials Journal. Vol. 101, No. 6, pp. 467472.

Huntzinger, D.N. and T.D. Eatmon, 2009, "A LifeCycle Assessment of Portland Cement Manufacturing: Comparing The Traditional Process With Alternative Technologies", Journal of Cleaner Production. Vol. 17 No. 77, pp. 668-675.

Kong, D.L.Y. and Sanjayan, J.G., 2010, "Effect of Elevated Temperatures on Geopolymer Paste, Mortar and Concrete", Cement and Concrete Research. Vol. 40, No. 2, pp. 334-339.

Li, C., Gong, X.Z., Cui, S.P., Wang, Z.H., Zheng, Y. and Chi, B.C., 2011, " $\mathrm{CO}_{2}$ Emissions Due to Cement Manufacture", Materials Science Forum. Vol. 685 No. 1, pp. 181-187.

Meyer, C., 2009, "The Greening of The Concrete Industry", Cement and Concrete Composites. Vol. 31, No. 8, pp. 601-605.
Nath, P. and Sarker, P.K., 2015, "Effect of GGBFS on Setting, Workability and Early Strength Properties of Fly Ash Geopolymer Concrete Cured in Ambient Condition", Construction and Building Materials. Vol. 66, pp. 163-171.

Peng, J.X., Huang L., Zhao, Y.B., Chen P., Zeng, L., and Zhen W., 2013, "Modeling of Carbon Dioxide Measurement on Cement Plants", Advanced Materials Research. Vol. 610-613, pp. 2120-2128.

Provis, J.L., 2014, "Geopolymer and Other Alkali Activated Materials: Why, How and What?", Materials and Structures. Vol. 47, No. 1-2, pp. 11-25

Singh, B., Ishwarya, G., Gupta, M., Bhattacharyya, S.K., 2015, "Geopolymer Concrete: A Review of Some Recent Developments", Construction and Building Materials. Vol. 85, No. June, pp. 78-90.

Soutsos, M., Boyle, A.P., Vinai R., Hadjierakleous, A., and Barnett, S.J., 2016, "Factors Influencing The Compressive Strength of Fly Ash Based Geopolymers", Construction and Building Materials. Vol. 110, No. May, pp. 355-368.

Wardhono, A., 2015, “The Durability of Fly Ash Geopolymer and Alkali-Activated Slag Concretes", Master Thesis. Royal Melbourne Institute of Technology (RMIT) University, Melbourne, Australia. 